\title{
DIABASE DYKE SWARMS AS STRUCTURAL CONTROLS FOR KIMBERLITE PIPES UNDER THE JAMES BAY AND HUDSON BAY LOWLANDS, ONTARIO
}

\author{
Greg M. Stott \\ Ontario Geological Survey, Canada
}

\section{LOWLAND DYKES}

An extensive Phanerozoic cover overlies the Archean Superior Province in northernmost Ontario and forms the James Bay (JBL) and Hudson Bay (HBL) lowlands (Figure 1). Diamondiferous kimberlite pipes of Early Jurassic (circa $190 \mathrm{Ma}$ ) and Mesoproterozoic (circa $1100 \mathrm{Ma})$ age are known to occur in two separate clusters in the James Bay Lowlands (Figure 2). It is generally recognized that the early Jurassic kimberlite pipes, including the Victor diamond deposit of De Beers Canada Exploration Inc., are close to the Winisk Fault, a major dextral transpressive fault formed probably during shortening of the Paleoproterozoic Trans-Hudson orogen against the northwestern Superior Province. However, this does not adequately account for the more scattered distribution, farther west, of Mesoproterozoic "Kyle" kimberlite pipes. Not all of the Kyle intrusions lie close to the Winisk Fault. An additional spatial association with the kimberlite pipes becomes apparent when Precambrian diabase dykes are considered.

\section{DYKES AND DIAMONDS}

A geological interpretation of regional aeromagnetic maps is being completed of the Precambrian basement underlying the Phanerozoic cover in the JBL and HBL. This analysis includes identification of the various Proterozoic diabase dyke swarms in that region. From this there is reason to suspect a spatial correspondence between both of these kimberlite pipe clusters and two diabase dyke swarms. The Early Jurassic pipes, near the Attawapiskat River in the James Bay Lowlands, mainly lie in a linear northwestward trend close to a Matachewan (ca. $2446 \mathrm{Ma}$ ) diabase dyke. This dyke is part of a parallel bundle of northwest-striking dykes across an approximately 20-kilometre width cut by the Winisk Fault. It is suggested here that the deep crustal fractures associated with these dykes, arising from the giant Matachewan magmatic event, were reopened during subsequent episodes of displacement along the Winisk Fault. Over $90 \mathrm{~km}$ farther west, the $2121 \mathrm{Ma}$ Marathon swarm forms an approx. 20 kilometre wide bundle of dykes trending northwards in the vicinity of the Kyle kimberlite pipes. Individual pipes lie close to

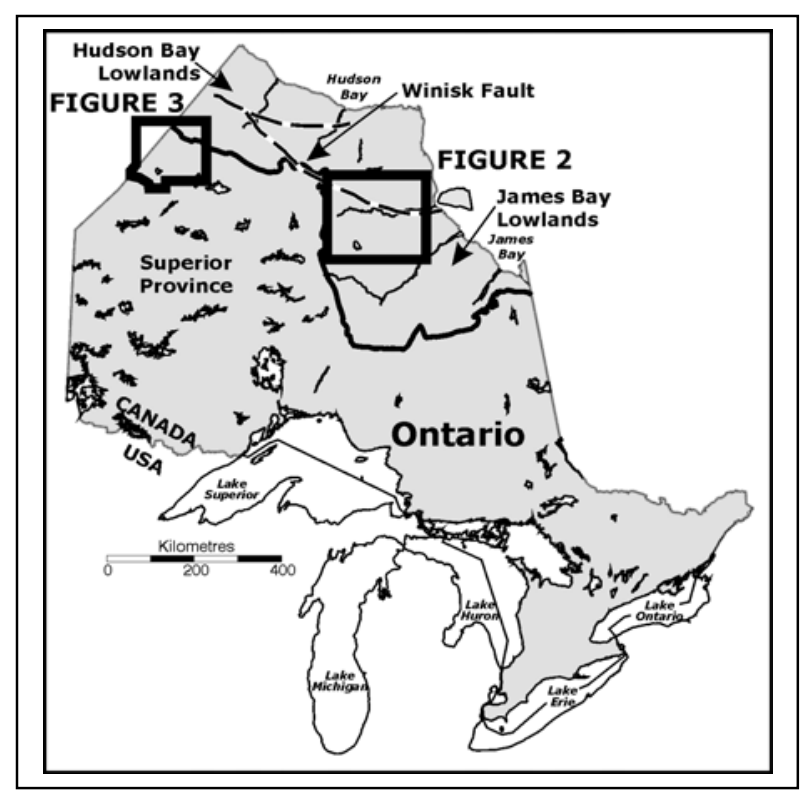

Figure 1: Map of Ontario showing the locations of Figures 2 and 3 and the James Bay and Hudson Bay lowlands. The Winisk fault underlies the Phanerozoic cover rocks of the lowlands.

aeromagnetic traces of the dykes. The occurrence of both sets of kimberlite pipes, close to but generally not on the Winisk Fault, implies the possibility that dykeassociated fracture swarms served as second-order, extensional "splays" near this major fault and provided preferred emplacement pathways for pipe intrusions at least in the middle to upper crust. One causative scenario from this model is that episodic craton-scale stress at circa $1100 \mathrm{Ma}$ and $190 \mathrm{Ma}$ induced reactivation of the Winisk fault and used the nearby vertically dipping dykes and fractures as surfaces controlling kimberlite pipe emplacement. Similar correlations have been inferred in the Lac de Gras area in the Slave Province where Paleoproterozoic dykes show a moderate to strong spatial association with kimberlite pipes (Wilkinson et al., 2001).

Approximately $60-80 \mathrm{~km}$ farther east of the Victor deposit, there is an overlap of another set of Matachewan and Marathon dyke bundles (see Figure 2) transected by the east-trending Winisk Fault, where no 


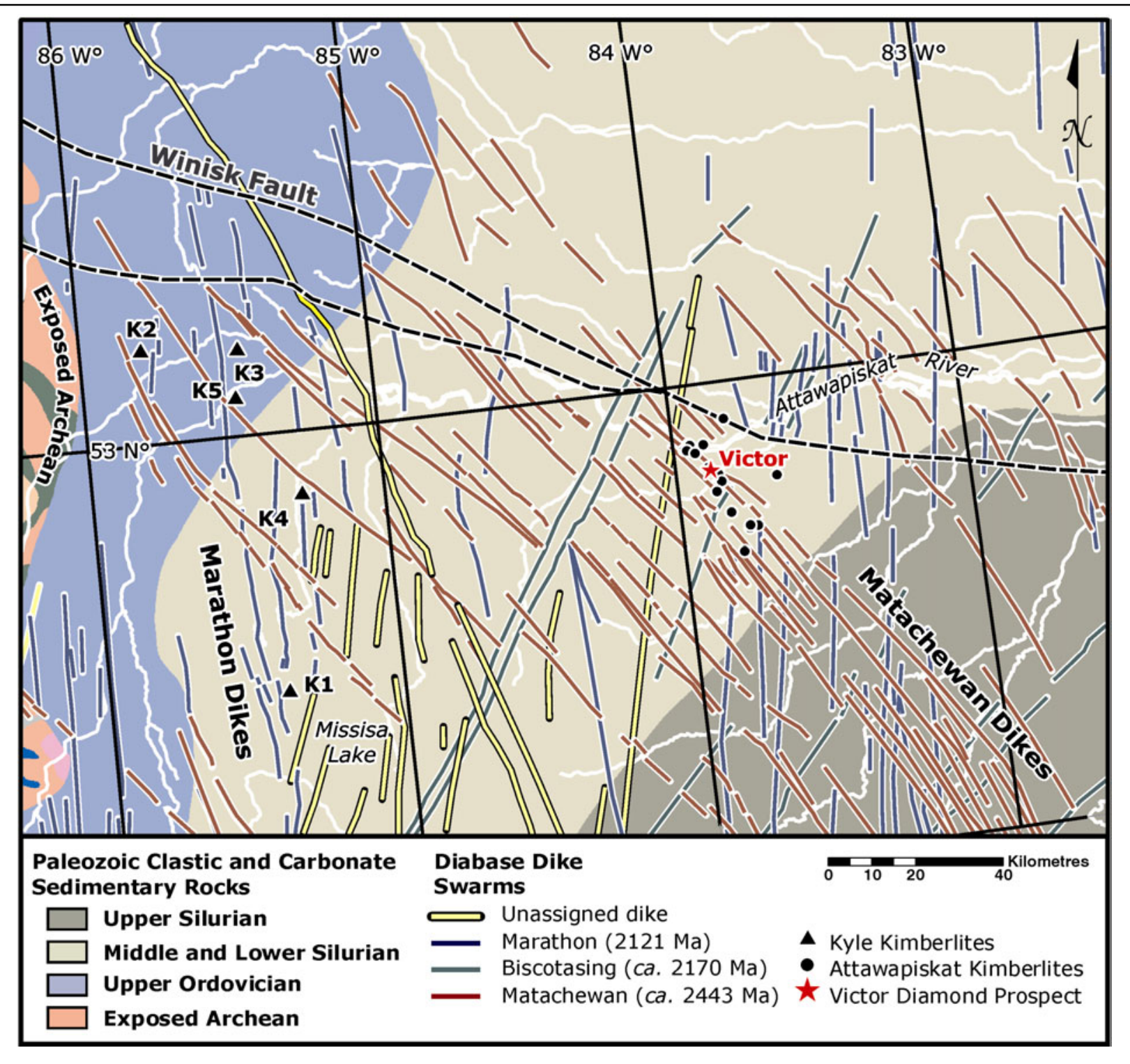

Figure 2: A map highlighting the distribution of diabase dyke swarms under the Phanerozoic cover rocks of the James Bay Lowlands and the spatial correlation with kimberlite pipes. Early Jurassic kimberlite pipes, near Attawapiskat River, including the Victor diamond deposit, concentrate in a train parallel to one dyke in a group of northwest-striking Matachewan (2446 Ma) diabase dykes and inferred associated fractures. Mesoproterozoic (1100 Ma) "Kyle" kimberlite pipes are spatially concentrated near individual diabase dykes in a group of north-striking Marathon (2121 Ma) dykes.

kimberlite pipes have as yet been discovered. In the context of this model, another area of potential exploration interest straddles the Manitoba - Ontario border near the Hudson Bay Lowlands (Figure 3) where a set of reversely magnetised, north-striking dykes (and fractures?) occur between the North Kenyon fault and

the Winisk fault. This dyke swarm occurs "up-ice" from an area of glacially deposited kimberlite indicator minerals found to the southwest (Stone 2001). These two areas in the James Bay Lowlands and near the Ontario-Manitoba border might serve as exploration tests of this empirically apparent correlation between pipe intrusions and dyke and fracture swarms, especially in proximity to the Winisk Fault. It is to be expected that the aeromagnetic expression of the pipes might be masked by the presence of these dykes. This is a testable hypothesis and further research requires dating of fracture materials in these diabase/fracture swarms. The apparent correspondence between kimberlite pipe emplacements and geophysically traceable bundles of diabase dykes and accompanying fractures provides a potentially important structural control, especially where subjected to reactivated tensile stress near major transcurrent faults. 


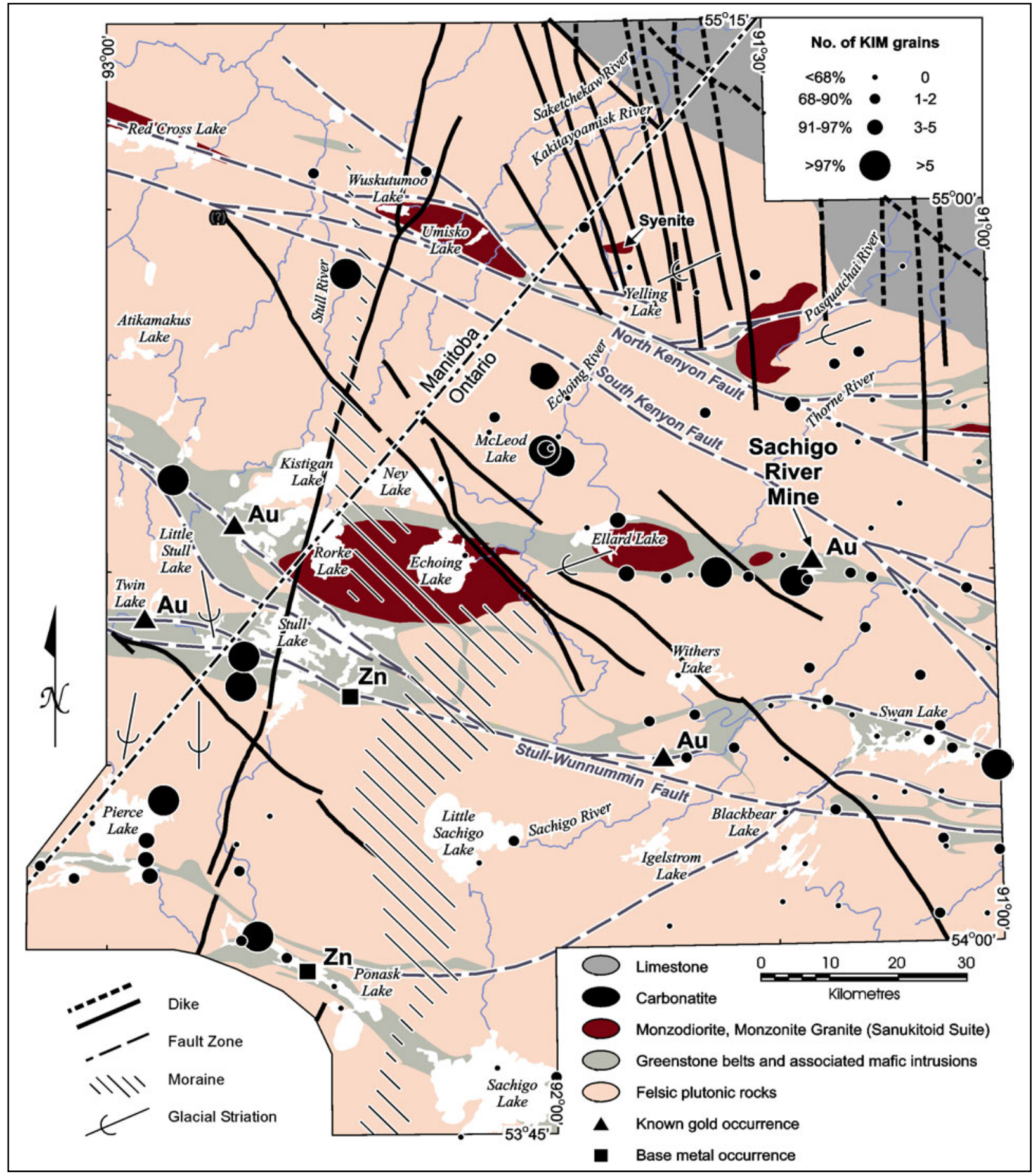

Figure 3: A map of a north-northwest-striking swarm of diabase dykes between the North Kenyon fault and the Winisk fault (north of the figure area). The dyke swarm is "up-ice" in relation to the glacial transport of kimberlite indicator minerals to the southwest. Figure modified from Stone (2001). This setting is similar to diabase dyke swarms near the Winisk fault in the James Bay Lowlands.

\section{REFERENCES}

Stone, D. 2001. A study of indicator minerals for kimberlite, base metals and gold: northern Superior Province of
Ontario; Ontario Geological Survey, Open File Report 6066, 140p.

Wilkinson, L., Kjarsgaard, B.A., LeCheminant, A.N. and Harris, J. 2001. Diabase dyke swarms in the Lac de Gras area, Northwest Territories, and their significance to kimberlite exploration: initial results; Geological Survey of Canada, Current Research 2001C8, 17p.

Contact: G.M. Stott, Ontario Geological Survey, 933 Ramsey Lake Road, Sudbury, ON, Canada, P3E 6B5, E-mail: greg.stott@ndm.gov.on.ca 